\title{
More than twenty years after the repeal of the Group Areas Act: housing, spatial planning and urban development in post-apartheid South Africa
}

\author{
Caroline Newton $\cdot$ Nick Schuermans
}

Published online: 7 June 2013

(C) Springer Science+Business Media Dordrecht 2013

\begin{abstract}
More than twenty years after the repeal of the Group Areas Act, South Africa is facing a number of challenges with regards to housing, spatial planning and urban development. Government institutions, scholars, NGO's and local communities have been looking for innovative ways to improve the housing conditions of all South Africans. With this special issue, we aim to demonstrate that international insights cannot only be relevant to understand and enrich South African cases, but that an in-depth analysis of the South African experiments can also be meaningful for academic analyses and political decisions in other parts of the world. In order to stimulate such a cross-fertilization, this article will briefly summarize the current situation in South Africa in the public housing sector, the private housing sector and the self-help approach. We will also introduce the eight papers of this special issue.
\end{abstract}

Keywords South Africa · Housing - Spatial planning · Urban development . Comparative urbanism

\section{Introduction}

Immediately after the repeal of the apartheid laws, the international academic community paid a lot of attention to the housing situation and the built environment in South Africa. While an academic boycott had blocked meaningful interactions between South African

C. Newton $(\square)$

The Bartlett Development Planning Unit, UCL, 34 Tavistock Square, London WC1H 9EZ, UK e-mail: Caroline.el.newton@ucl.ac.uk

N. Schuermans

Division of Geography, Department of Earth and Environmental Sciences, KU Leuven, Celestijnenlaan 200 E, 3001 Leuven, Belgium

e-mail: Nick.Schuermans@ees.kuleuven.be

N. Schuermans

Faculty of Architecture, KU Leuven, Campus Sint-Lucas Brussels, Paleizenstraat 65-67, 1030 Brussels, Belgium 
scholars and their colleagues from the rest of the world for most of the 1970s and 1980s, the 1990s were marked by a growing international interest in the spatiality of apartheid and post-apartheid cities. This interest seemed to work in both directions. On the one hand, local scholars argued to "move beyond the narrowness of our usual frame of reference in South African urban studies" (Parnell and Mabin 1995, p. 61) and to "close the door of an era of parochialism" (Rogerson 2000, p. 340). On the other hand, researchers from abroad visited the country and set up courses and research cooperations with local scholars (e.g. Lemon 1991; Smith 1992; Prinsloo et al. 1999).

Together with the initial enthusiasm about the rainbow nation, the attention for South African urban forms seems to have dwindled, however. Even though a lot of foreign scholars are still conducting research in South Africa (Schuermans and Newton 2012), the country seems to take up a less prominent place in the teaching and the writing of academics in urban studies and housing studies than it used to do. Reflecting upon this situation, Robinson (2003, p. 284) criticized the fact that South Africa has always been treated as an exceptional case and that "perilously little theoretical or generalisable learning has taken place by western scholars from our work". In a more recent article, Hammett (2012, p. 937) warns, once more, against tendencies in South African geography "towards parochialism, empiricism and disconnection from the international academy".

In our eyes, the lack of a dialogue between South African scholars and their colleagues in the rest of the world is problematic. More than 20 years after the repeal of the Group Areas Act, the country is facing a number of challenges with regards to houses, neighbourhoods and cities to be built. Government institutions, scholars, NGO's and local communities have been looking for innovative ways to improve the housing conditions of all South Africans. With this special issue, we aim to demonstrate that international insights cannot only be relevant to understand and enrich South African cases, but that an in-depth analysis of the South African experiments can also be meaningful for academic analyses and political decisions in other parts of the world. In order to stimulate such a cross-fertilization, this article will briefly summarize the current situation of housing, spatial planning and urban development in South Africa. Following Landman and Napier (2010), we will differentiate between three strands of housing provision: the public sector, the private sector and the self-help approach.

\section{The public sector}

In 1994, the new government was confronted with a huge housing backlog. More than 1.5 million informal units in urban areas were not located on titled land, but in informal settlements. Apart from the millions of rural dwellers living in bad conditions, the residents of urban hostels and shack dwellers on registered plots expected better living circumstances as well (Bond and Tait 1997, p. 32). Against this background, the government promised to build one million new houses within 5 years after inauguration (Huchzermeyer 2003). These new houses were also supposed to be make the existing cities more compact and more integrated. In the 'Urban Development Framework', it was stated, for example, that new urban settlements should be "spatially and socio-economically integrated, free of racial and gender discrimination and segregation and enabling people to make residential and employment choices to pursue their ideals" (National Department of Housing 1997, p. iii).

While the government aimed to provide as many houses as quickly as possible, the results were unsatisfactory. The realization of vast quantities of dwellings did, in the main, 
occur through a project linked subsidy. This meant that a fixed subsidy was provided for each unit constructed, which then became the applicant's property. The subsidy did not only have to meet the costs of construction, but also the purchase of the land and the provision of the necessary infrastructure. Because of time pressures and financial restrictions, most new houses were located in large developments on the outskirts of the cities (Huchzermeyer 2003). As a consequence, the project linked subsidy system has been said to sustain - or even reinforce-the existing patterns of spatial segregation and social inequality (Huchzermeyer 2001).

In the following years the government has tried, however, to respond to the concerns and comments of experts, NGO's and grassroots movements (see Urban Sector Network 2003 for an example). Successive housing policies developed by the government have incorporated a more interventionist approach and the use of the subsidiarity principle (McLean 2003; Rust 2006). By the end of 2006, Social Housing Institutes were asked to align their programs with local needs and to give priority to the most vulnerable groups. In order to empower these groups, the beneficiaries needed to be actively involved through consultation, communication and education. More attention also needed to be paid to a selection of sites with easy access to jobs and services (Department of Housing 2006). The upgrading of informal settlements has also become a key concern in government programs (Huchzermeyer 2009).

Despite all these efforts, the broader aim of re-integrating South-African cities remains a difficult quest. It has to be acknowledged, indeed, that the high levels of segregation dating from the apartheid times are not easily counteracted. In fact, many poor households remain anchored in badly located neighborhoods. To explain this situation, Rust (2006, 2007) does not only point to the fact that most capital subsidies have been used on peripheral land, but also to the depreciation in the financial value of the subsidized houses. This means that families who want to improve their living conditions (an initial government intention) are generally unable to do so. In a critical assessment of the human settlement policy, Bradlow et al. (2011) stress that the government has focused too strongly on delivering formal housing solutions and that they have missed the chance to set up a true people-centered approach. In such an approach, structural definitions of housing would be complemented by more symbolic and intangible meanings of what it means to live somewhere, to create a home and a living.

All in all, this special issue contains four articles on the public sector in South Africa. Three articles focus on the upgrading of existing neighborhoods. In a first article, Massey (2013) investigates the techniques to upgrade informal settlements and their effects on local social networks. Using data from two neighborhoods in Cape Town, she demonstrates that there is a conflict between the technocratic approach of the city council and the needs of the local inhabitants. After showing that the current approach does not ensure the maintenance of strong social relationships, she pleads for more sustainable upgrading projects which depart from an understanding of the survival strategies of the poor.

In a second article on the upgrading of informal settlements, Shortt and Hammett (2013) focus on health issues. Drawing on surveys collected in the informal settlement of Imizamo Yethu (Cape Town), they shed light on the relationship between the in situ upgrading of informal settlements and health outcomes. By looking at four interrelated dimensions of housing defined by the World Health Organization - the physical structure of the house, the home, the neighborhood infrastructure and the community-they conclude that residents of formal housing and shack dwellers do not show any significant differences in terms of self-reported physical health. Nevertheless, the former are less likely to report mental health issues than the latter. Residents of formal houses also have a stronger sense 
of belonging and report greater satisfaction with both neighborhoods and homes than shack dwellers.

In a third article, Donaldson et al. (2013) do not concentrate on the effects of urban renewal processes, but on the methodologies and techniques to achieve them. In their analysis of two pilot projects in Cape Town, they demonstrate how urban renewal projects can benefit from an area based approach. Looking at the way in which public funds have been invested in two of the biggest townships of Cape Town, they stress the importance of an intermediary project management organization. According to Donaldson et al., this intermediary organization should not only apply for funding; it should also provide all partners with the necessary input for informed decision making on spatial, social, economic and infrastructural improvements in the area.

In the opening contribution, Parnell and Crankshaw (2013) look at the role of the state from a wider perspective. In fact, they argue that contemporary spatial policies to redress dysfunctional spatial configurations are hampered by traditionalist views that the countryside is the home of most victims of apartheid. In their opinion, social and spatial inequalities will be perpetuated until politicians come to realize that the majority of South Africans is housed in urban areas and that more than half of the Black African population has migrated to these areas as well. Nowadays, spatial policies targeting economic growth, poverty reduction and environmental integrity continue to be inspired by the faulty premise that the erosion of apartheid racial distributions is the best way to inform the spatial focus of the limited resources. In-stead, Parnell and Crankshaw advocate a spatial reorientation of the developmental agenda in which urban areas assume a greater prominence in government budgets.

\section{Self-help housing}

Towards the end of the 1960s, scholars in Latin America started to believe that self-help housing could be a viable response to the inability of many governments to solve the housing backlog (Ward 1978). Inspired by the work of John Turner in Mexico, the approach quickly received wider support and got picked up by international institutions such as the World Bank. Assisted self-help housing schemes were being appropriated as a strategy to answer the proliferation of informal settlements in the global South (Ntema 2011 , p. 2). In nearly all developed countries, self-provided housing has been a major form of housing supply as well (Duncan and Rowe 1993). As a result, some countries have percentages of self-help housing ranging from 30 to 70 (Pugh 2001, p. 400).

In South Africa, many communities have improved their housing situation from below. At present, the Federation of the Urban Poor is the largest organization that supports the self-help approach. Although the organization was only established in 2006, the roots of its predecessor lie in 1991. At a time when political prisoners were being released and previously prohibited organizations were being legalized, a conference gathered development practitioners, scholars and community leaders. At the conclusion of the conference, a mandate was given to the organizers to set up and sustain a network of the urban poor in which collectives could work together on self-help housing solutions (Bauman et al. 2004). This was the beginning of the People's Dialogue on Land and Shelter.

These grassroots approaches have inspired consecutive South African governments to develop their own mechanisms to promote and assist self-help housing solutions (Newton 2012). Already in 1998, the government launched the so-called "people's housing process" (PHP) (Jenkins 1999). In 2008, it went through a thorough make-over, using insights 
and comments from the NGO's who had been using the approach. The beneficiaries are still the main decision makers in a PHP project. They are also involved in every step of the housing process.

In this special issue, two articles focus on the self-help approach. In a first article, Newton (2013) illustrates the importance of the PHP policy as a key instrument for housing provision in South Africa. Drawing on two case studies in Cape Town, she demonstrates that PHP projects generally result in better quality dwellings and that the inhabitants are also more satisfied with them. Starting from the idea that houses should not only be shelters, but also homes, she argues that state actors and NGO's can support communities and realize an increasing number of PHP projects with them.

A second article on self-help housing has been written by Shapurjee and Charlton (2013). On the one hand, the authors argue that backyard dwellings are often said to symbolize the kind of informality and disorder that the South African government tries hard to overcome. Based on interviews in Alexandra (Johannesburg), they also demonstrate, however, that backyard dwellings provide the owners of state-subsidized houses with additional rooms for family members or with additional income from rent, while the occupiers of backyard dwellings are happy to find cheap rental accommodation which is immediately available. Along with Lemanski (2009), Shapurjee and Charlton, therefore, advocate to see backyard accommodation—and self-help housing more general—as an opportunity rather than an example of failed policy.

\section{The private sector}

In the framework provided by Landman and Napier (2010, p. 301), private sector housing refers to "housing that is delivered and/or financed by the private sector". Their definition includes both individuals having their own houses built by contractors and large scale housing developments constructed by large developers. Most houses and neighborhoods produced by private developers are the more typical suburban neighborhoods and clusters of apartments and/or townhouses.

In South Africa, it is often stated that the developments by the private sector reproduce the brutal social and spatial inequalities of the country. After an analysis of the fences, the walls and the gates around security complexes and gated communities, Lemanski (2004, p. 101) argued, from a spatial perspective, that "attempts to mitigate fear have resulted increasingly in the creation of fortified enclaves" and that such "citizen responses lead to increased segregation and a 'new apartheid' that bears frightening similarities to old apartheid structures". From a social point of view, Rust (2006, p. 21-22; 2007) added that the private housing market is catering more and more for the up-market segment and that only less than $10 \%$ of South Africans are currently able to afford an "affordable house" (defined by ABSA bank as a $40-74 \mathrm{~m}^{2}$ house, valued at $<\mathrm{R} 228000$ ).

To counterbalance these social and spatial trends, the South African government and local city councils have adopted a couple of policies. To encourage the construction of affordable units, the government has cooperated with the banking sector in order to set up the financial service charter. By allowing more lower income families to access mortgages, a first attempt is made to bridge the gap that is currently present on the housing provision ladder. With regards to the spatial fragmentation caused by the enclosure of streets and neighborhoods, September 2004 was a pivotal moment. In that month, the South African Human Rights commission declared the erection of boom gates and other measures of enclosure a violation of the human rights (Lemanski et al. 2008, p. 135). This judgment 
Fig. 1 Top: Distribution of case study neighborhoods discussed in this special issue according to Landman and Napier's (2010) threefold scheme. Bottom: Map of Capetonian neighborhoods discussed in this special issue

encouraged a lot of city councils across the country to implement stricter guidelines with respect to road closures and fenced-off neighborhoods (Lemanski et al. 2008).

In this special issue, two articles concentrate on the private sector. Klug et al. (2013) draw on two case studies in Johannesburg to look at the opportunities and challenges facing inclusionary housing policies. In these policies, private developers are forced to integrate some affordable housing in their higher-income developments. Apart from institutional and legal issues, key constraints include resistance by property developers and protests by upper-income residents. Referring to European and American debates on social mix and discussions on inclusionary housing in other developing countries, the authors conclude that there are limits to the extent to which inclusionary housing can contribute to socio-economic desegregation.

From a completely different point of view, Schuermans (2013) looks at private houses as places of encounter. Drawing on in-depth interviews with 78 residents of two Capetonian neighborhoods, he looks into the complex geographies of encounter within the fortified houses of white, middle class South Africans. His results demonstrate that seemingly banal actions to secure homes are not only targeting a reduction of crime and fear of crime, but also the socio-spatial exclusion of poor people. Yet, seemingly contradictorily, the same homes also provide one of the rare places where encounters with domestic workers and builders help to shatter stereotypes and encourage practices of generosity.

\section{Conclusion}

In the three preceding sections, the eight contributions to this special issue have been positioned with respect to the threefold division by Landman and Napier (2010). Even though every attempt to classify case-studies in their scheme runs the risk of over-simplification, Fig. 1 tries to visualize the position of each case-study within the public sectorprivate sector-self-help approach division. The map visualizes the geographical position of the ten neighbourhoods discussed in the five articles about Cape Town. For a map locating the four neighbourhoods discussed in the two contributions about Johannesburg, we refer to the papers by Shapurjee and Charlton (2013) and Klug et al. (2013).

From the short descriptions of the articles, it should be clear that most authors do not focus on one type of housing, but on the crucial overlaps between different types of dwellings. While Shortt and Hammett (2013) look at the health differences between shack dwellers and residents of formal housing, Shapurjee and Charlton (2013) focus on the interactions between publicly provided dwellings and the self-built shacks in their backyards. And while Schuermans (2013) is interested in practices of generosity between middle class Whites living in private houses and domestic workers living in poor neighbourhoods or informal settlements, Klug et al. (2013) look at the possibility of affordable housing in middle-class projects by private developers. Because the different articles in this special issue discuss different aspects of the same questions about housing, spatial planning and urban development, we hope that a relational reading of the concrete case studies addressed in the different articles will stimulate readers to see the challenges and the opportunities affecting the built environment in South Africa from a cross-case perspective (cf. Graham and Healey 1999; Jones 2009). 


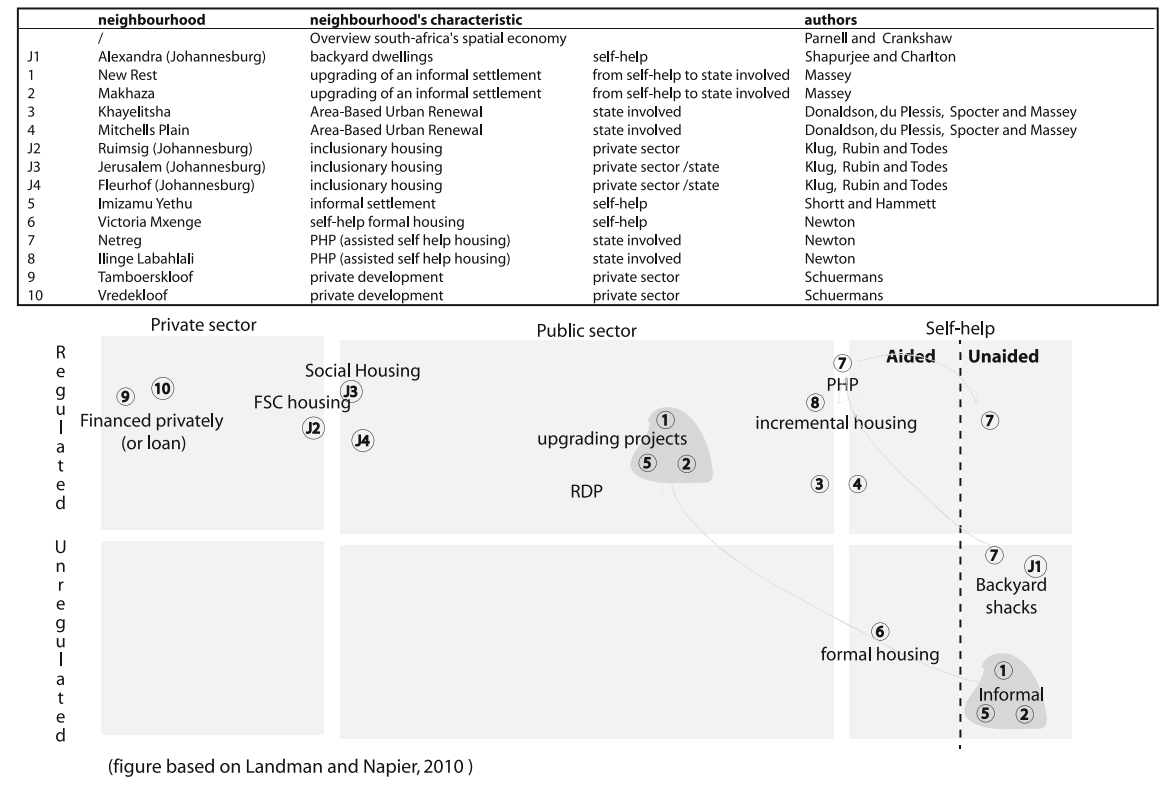

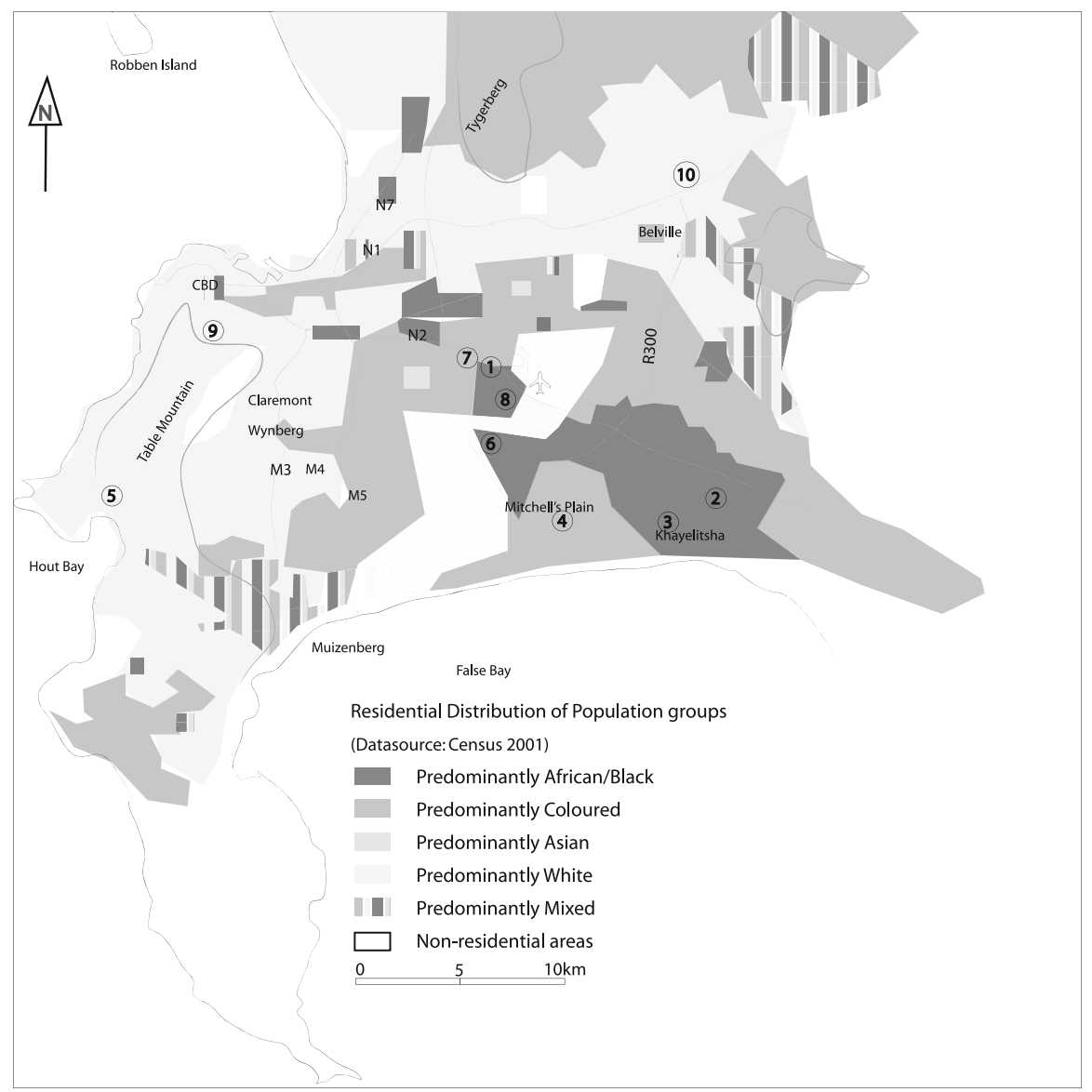


Looking back at the first paragraphs of this introductory article, we actually believe that a relational reading of the eight papers does not only allow for an analysis that cuts across the diversity of case-studies in different cities, but also for an understanding that transcends the differences between the contexts from which the cases have been written and the ones from which they will be read. Inspired by scholars such as Kevin Ward and Jennifer Robinson, we are convinced, indeed, that a relational understanding of cities should not only permeate our investigations of social and spatial processes taking place within a particular city, but also the geographies of theory production which underlay such investigations. While Ward (2008, p. 407) draws on the idea of relational space to argue that the "challenge for any future scholarship on comparative urbanism is to move away from understanding cities as discrete, self-enclosed and analytically separate projects", Robinson (2006, p. 138) concludes that "any research on cities needs to be undertaken in a spirit of attentiveness to the possibility that cities elsewhere might perhaps be different and shed stronger light on the processes being studied". Even though the eight papers collected in this special issue are firmly rooted in the specificities of the South African context, we hope, therefore, that they may inspire academics and professionals working on topics ranging from inclusionary housing and self-help approaches to urban renewal and settlement upgrading all over the world.

\section{References}

Bauman, T., Bolnick, J., \& Mitlin, D. (2004). The age of cities and organizations of the urban poor: The work of the South African Homeless People's Federation. In D. Mitlin \& D. Satterthwaite (Eds.), Empowering squatter citizen (p. 304). London: Earthscan.

Bond, P., \& Tait, A. (1997). The failure of housing policy in post-apartheid South Africa. Urban Forum, $8(1), 19-41$.

Bradlow, B., Bolnick, J., \& Shearing, C. (2011). Housing, institutions, money: The failures and promise of human settlements policy and practice in South Africa. Environment and Urbanization, 23(1), 267-275.

Department of Housing. (2006). Social housing bill. (Bill published in Government Gazette No. 29339 of 3 November 2006 and No. 30022 of 6 July 2007).

Donaldson, R., du Plessis, D., Spocter, M. \& Massey, R. (2013). The South African area-based urban renewal programme: Experiences from Cape Town. Journal of Housing and the Built Environment (this issue).

Duncan, S. S., \& Rowe, A. (1993). Self-provided housing: The first world's hidden housing arm. Urban Studies, 30(8), 1331-1354.

Graham, S., \& Healey, P. (1999). Relational concepts of space and place: Issues for planning theory and practice. European Planning Studies, 7(5), 623-646.

Hammett, D. (2012). W(h)ither South African human geography? Geoforum, 43(5), 937-947.

Huchzermeyer, M. (2001). Housing for the poor? Negotiated housing policy in South Africa. Habitat International, 25(3), 303-331.

Huchzermeyer, M. (2003). Low income housing and commodified urban segregation in South-Africa. In C. Haferburg \& J. Oßenbrügge (Eds.), Ambiguous restructurings of post-apartheid Cape Town: The spatial form of socio-political change. Münster: Lit verlag.

Huchzermeyer, M. (2009). The struggle for in situ upgrading of informal settlements: A reflection on cases in Gauteng. Development Southern Africa, 26(1), 59-73.

Jenkins, P. (1999). Difficulties encountered in community involvement in delivery under the new South African housing policy. Habitat International, 23(4), 431-446.

Jones, M. (2009). Phase space: Geography, relational thinking, and beyond. Progress in Human Geography, 33(4), 487-506.

Klug, N., Rubin, M. \& Todes, A. (2013). Inclusionary housing policy: A tool for re-shaping South Africa's spatial legacy? Journal of Housing and the Built Environment (this issue). 
Landman, K., \& Napier, M. (2010). Waiting for a house or building your own? Reconsidering state provision, aided and unaided self-help in South Africa. Habitat International, 34(3), 299-305.

Lemanski, C. (2004). A new apartheid? The spatial implications of fear of crime in Cape Town, South Africa. Environment and Urbanization, 16(2), 101-112.

Lemanski, C. (2009). Augmented informality: South Africa's backyard dwellings as a by-product of formal housing policies. Habitat International, 33(4), 472-484.

Lemanski, C., Landman, K., \& Durington, M. (2008). Divergent and similar experiences of 'gating' in South Africa: Johannesburg, Durban and Cape Town. Urban Forum, 19(2), 133-158.

Lemon, A. (Ed.). (1991). Homes apart: South Africa's segregated cities. London: Paul Chapman.

Massey, R. (2013). Competing rationalities and informal settlement upgrading in Cape Town, South Africa: A recipe for failure. Journal of Housing and the Built Environment (this issue).

McLean, K. (2003). Housing provision through co-operative government in post-apartheid South-Africa. In G. Mhone \& O. Edigheji (Eds.), Governance in the new South-Africa: The challenges of globalisation (p. 368). Cape Town: University of Cape Town Press.

National Department of Housing. (1997). Urban development framework. http://www.info.gov.za/view/ DownloadFileAction?id=70505.

Newton, C. (2012). Victoria Mxenge: A story about more than women building their community. Urban Forum, 23(2), 197-207.

Newton, C. (2013). The people's housing process. Getting the quality in the quantity? Journal of Housing and the Built Environment (this issue).

Ntema, L. J. (2011). Self-help housing in South Africa: Paradigms, policy and practice. Unpublished PhD thesis, Faculty of Economic and Management Sciences, Centre for Development Studies. University of the Free State, Bloemfontein.

Parnell, S. \& Crankshaw, O. (2013). The politics of 'race' and the transformation of the post-apartheid space economy. Journal of Housing and the built Environment (this issue).

Parnell, S., \& Mabin, A. (1995). Rethinking urban South Africa. Journal of Southern African Studies, 21(1), $39-61$.

Prinsloo, R., Verbeke, M., \& Vanneste, D. (1999). South Africa: Spatial transformations in the postapartheid era, manual with the website course. Leuven: Acco.

Pugh, C. (2001). The theory and practice of housing sector development for developing countries, 1950-1999. Housing Studies, 16(4), 399-424.

Robinson, J. (2003). Postcolonialising geography: Tactics and pitfalls. Singapore Journal of Tropical Geography, 24, 273-289.

Robinson, J. (2006). Ordinary cities: Between modernity and development. London: Routledge.

Rogerson, C. M. (2000). The economic and social geography of South Africa: Progress beyond apartheid. Tijdschrift voor Economische en Sociale Geografie, 91(4), 335-346.

Rust, K. (2006). Analysis of South Africa's housing sector performance. FinMark Trust.

Rust, K. (2007). It's time for some innovation. Access Housing Newsletter, 7, 7.

Schuermans, N. (2013). Ambivalent geographies of encounter in and around the fortified homes of middle class whites in Cape Town. Journal of Housing and the Built Environment (this issue).

Schuermans, N., \& Newton, C. (2012). Being a young and foreign researcher in South Africa: Towards a post-colonial dialogue. Singapore Journal of Tropical Geography, 33(3), 295-300.

Shapurjee, Y. \& Charlton, S. (2013). Transforming South Africa's low-income housing projects through backyard dwellings: Intersections with households and the state in Alexandra, Johannesburg. Journal of Housing and the Built Environment (this issue).

Shortt, N. \& Hammett, D. (2013). Housing and health in an informal settlement upgrade in Cape Town, South Africa. Journal of Housing and the Built Environment (this issue).

Smith, D. (Ed.). (1992). The apartheid city and beyond: Urbanization and social change in South Africa. London: Routledge.

Urban Sector Network. (2003). Evaluation of the national housing subsidy scheme. Produced for The office of the public service commission. report.

Ward, P. M. (1978). Self-help housing in Mexico City: Social and economic determinants of success. Town Planning Review, 49(1), 38-50.

Ward, K. (2008). Toward a comparative (re)turn in urban studies? Some reflections. Urban Geography, 29(5), 405-410. 